\title{
Nadciśnienie tętnicze w okresie laktacji - czy zawsze należy leczyć?
}

\section{Hypertension during lactation - should it always be treated?}

\author{
Anna Michalska ${ }^{1}$, Iwona Gorczyca ${ }^{2}$, Olga Jelonek ${ }^{2}$, Beata Wożakowska-Kapłon ${ }^{2,3}$ \\ ${ }^{1}$ Studenckie Koło Naukowe przy Wydziale Lekarskim Uniwersytet Jana Kochanowskiego w Kielcach \\ ${ }^{2}$ IKlinika Kardiologii I Elektroterapii Świętokrzyskiego Centrum Kardiologii w Kielcach \\ ${ }^{3}$ Wydział Lekarski i Nauk o Zdrowiu Uniwersytetu Jana Kochanowskiego w Kielcach
}

\section{Streszczenie}

Opisano 40-letnią pacjentkę w pierwszej ciąży, u której rozpoznano nadciśnienie tętnicze indukowane ciążą. W okresie ciąży u omawianej chorej uzyskano docelowe wartości ciśnienia tętniczego, stosując metyldopę. W okresie połogu stosowane w trakcie ciąży leczenie hipotensyjne okazało się niewystarczające. Przedstawiono postępowanie w ramach leczenia hipotensyjnego u karmiącej pacjentki.

Słowa kluczowe: nadciśnienie tętnicze, laktacja, metyldopa

Folia Cardiologica 2018; 13, 2: 169-172

\section{Wstęp}

Nadciśnienie tętnicze (AH, arterial hypertension) u kobiet w okresie ciąży może niekorzystnie wpływać na stan zdrowia zarówno matki, jak i dziecka [1]. W przypadku AH wywołanego ciążą (z białkomoczem lub bez niego) farmakoterapia jest wskazana wtedy, gdy wartość ciśnienia tętniczego (BP, blood pressure) wynosi 140/90 mm Hg lub więcej. U kobiet w okresie w ciąży z uprzednio istniejącym $\mathrm{AH}$, niepowikłanym i bezobjawowym, zaleca się leczenie farmakologiczne od wartości większych lub równych 150/95 mm Hg. Wartość BP wynoszącą 170/110 mm Hg i wyższą należy traktować jako wskazanie do hospitalizacji. Według wytycznych Polskiego Towarzystwa Nadciśnienia Tętniczego (PTNT) występowanie choroby nadciśnieniowej u kobiet w okresie ciąży jest wskazaniem do wykonania całodobowej rejestracji ciśnienia tętniczego (ABPM, ambulatory blood pressure monitoring) [3]. W czasie połogu utrzymujące się
AH u kobiety oraz karmienie piersią warunkują stosowanie farmakoterapii zalecanej w okresie ciąży. Ze względu na fakt, że wszystkie leki hipotensyjne przenikają do mleka kobiecego, w czasie laktacji należy stosować preparaty bezpieczne dla zdrowia dziecka [2].

\section{Opis przypadku}

Pacjentka w wieku 40 lat, wcześniej nieleczona przewlekle, w 23. tygodniu pierwszej ciąży trafiła do poradni kardiologicznej z powodu AH rozpoznanego przez lekarza ginekologa. Nieprawidłowe wartości BP zaobserwowano w 23. i 24. tygodniu ciąży, w 2-krotnie wykonanych gabinetowych (OBPM, office blood pressure measurement) oraz domowych pomiarach ciśnienia tętniczego (HBPM, home blood pressure monitoring).W poprzednich tygodniach regularnie wykonywano OBPM, nie stwierdzając nieprawidłowości. Wyniki pomiarów BP przed leczeniem zawarto w tabeli 1. 
Tabela 1. Wyniki pomiarów ciśnienia tętniczego przed włączeniem leczenia

\begin{tabular}{|c|c|c|c|}
\hline \multirow{2}{*}{$\begin{array}{l}\text { Numer porządkowy } \\
\text { pomiaru ciśnienia }\end{array}$} & \multicolumn{3}{|c|}{ Typ pomiaru } \\
\hline & $\begin{array}{l}\text { OBPM u lekarza ginekologa } \\
\text { [mm Hg] }\end{array}$ & HBPM [mm Hg] & $\begin{array}{l}\text { OBPM u lekarza kardiologa } \\
\text { [mm Hg] }\end{array}$ \\
\hline 1. & $138 / 89$ & $140 / 80$ & $145 / 95$ \\
\hline 2. & $145 / 89$ & $135 / 80$ & $140 / 85$ \\
\hline 3. & $142 / 92$ & $139 / 92$ & $132 / 79$ \\
\hline
\end{tabular}

OBPM (office blood pressure measurement) - gabinetowy pomiar ciśnienia tętniczego; HBPM (home blood pressure monitoring) - domowy pomiar ciśnienia tętniczego

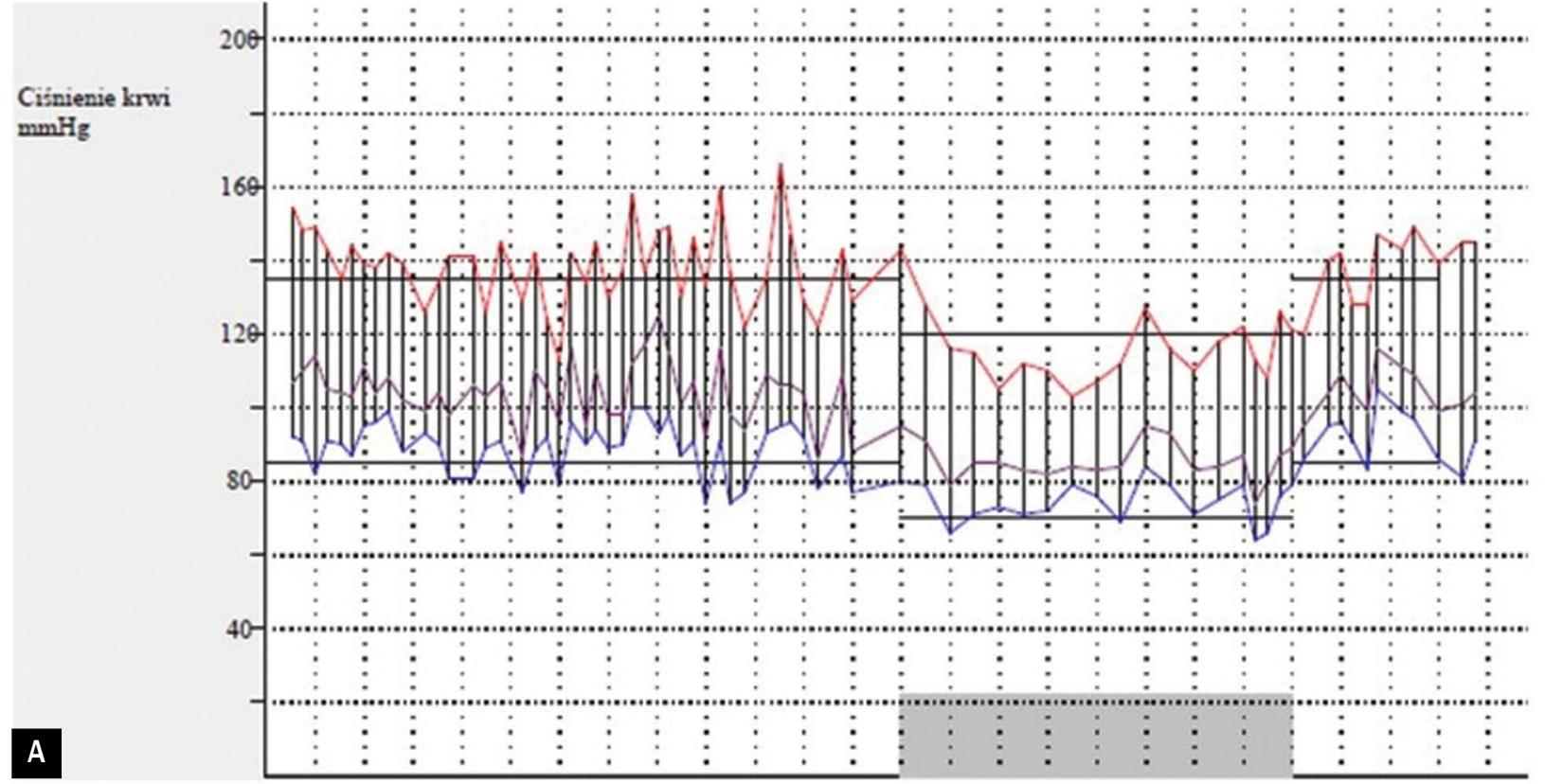

\begin{tabular}{|c|c|c|c|c|c|c|c|}
\hline \multicolumn{8}{|c|}{ Czas trwania monitorowania: 24 godz. 2 min } \\
\hline \multicolumn{4}{|c|}{ Okres snu: 22:00-6:00 } & \multicolumn{4}{|c|}{ Godzina wstania z łóżka: 6:30 } \\
\hline \multicolumn{8}{|c|}{ Liczba pomiarów poddawanych interpretacji: 78 z 79 (98,7\%) } \\
\hline \multicolumn{8}{|c|}{ Liczba interpretowanych pomiarów (łącznie/dzień/noc): 78/63/15 } \\
\hline & & SBP & DBP & & & SBP & DBP \\
\hline \multirow{3}{*}{$\begin{array}{l}\text { Średnia wartość BP } \\
{[\mathrm{mm} \mathrm{Hg]}}\end{array}$} & Cała doba & 133 & 85 & \multirow{3}{*}{$\begin{array}{c}\text { Minimalna wartość BP } \\
{[\mathrm{mm} \mathrm{Hg}]}\end{array}$} & & & \\
\hline & Czuwanie & 138 & 89 & & Czuwanie & 113 & 74 \\
\hline & Sen & 116 & 74 & & Sen & 103 & 64 \\
\hline \multirow[t]{3}{*}{ Ładunek BP (\%) } & & & & \multirow{3}{*}{$\begin{array}{c}\text { Maksymalna wartość } \\
\text { BP [mm Hg] }\end{array}$} & & & \\
\hline & Czuwanie & 63 & 76 & & Czuwanie & 166 & 105 \\
\hline & Sen & 23 & 77,8 & & Sen & 143 & 84 \\
\hline \multirow[t]{3}{*}{ Dobowy profil BP (\%) } & Nocny spadek BP (\%) & 16 & 16 & \multirow[t]{3}{*}{ Zmienność BP (SD) } & Cała doba & 10,2 & 8,5 \\
\hline & \multirow[t]{2}{*}{ Poranny wzrost BP (\%) } & \multirow[t]{2}{*}{7,9} & \multirow[t]{2}{*}{12,2} & & Czuwanie & 8,3 & 9 \\
\hline & & & & & Sen & 10 & 10 \\
\hline
\end{tabular}

Rycina 1A, B. Wynik całodobowego monitorowania ciśnienia tętniczego; SBP (systolic blood pressure) - skurczowe ciśnienie tętnicze; DBP (diastolic blood pressure) - rozkurczowe ciśnienie tętnicze; BP (blood pressure) - ciśnienie tętnicze; SD (standard deviation) - odchylenie standardowe 
Tabela 2. Wyniki pomiarów ciśnienia tętniczego po włączeniu leczenia

\begin{tabular}{|c|c|c|c|}
\hline $\begin{array}{l}\text { Czas wizyty } \\
\text { kontrolej }\end{array}$ & Nr pomiaru & $\begin{array}{c}\text { OBPM } \\
\text { [mm Hg] }\end{array}$ & $\begin{array}{c}\text { HBPM } \\
{[\mathrm{mm} \mathrm{Hg}]}\end{array}$ \\
\hline \multirow[t]{3}{*}{ 25. tc. } & 1. & $141 / 89$ & $142 / 99$ \\
\hline & 2. & $140 / 85$ & $138 / 80$ \\
\hline & 3. & $137 / 88$ & $135 / 80$ \\
\hline \multirow[t]{3}{*}{ 30. tc. } & 1. & $137 / 70$ & $133 / 79$ \\
\hline & 2. & $135 / 86$ & $138 / 81$ \\
\hline & 3. & $130 / 80$ & $131 / 84$ \\
\hline \multirow[t]{3}{*}{34 tc. } & 1. & $137 / 80$ & $128 / 83$ \\
\hline & 2. & 131/82 & $129 / 82$ \\
\hline & 3. & $129 / 80$ & $131 / 80$ \\
\hline
\end{tabular}

Badanie moczu nie wykazało odchyleń od normy. W badaniach laboratoryjnych nie stwierdzono nieprawidłowości. Wykonano ABPM, w którym stwierdzono nieprawidłowe wyniki średnich wartości ciśnień z uwzględnieniem aktualnego tygodnia ciąży (ryc. 1). Na podstawie wyników ABPM, OBPM i HBPM rozpoznano AH. Ponieważ schorzenie rozpoznano po 20. tygodniu ciąży, to zakwalifikowano je jako $\mathrm{AH}$ wywołane ciążą $[3,4]$.

Włączono leczenie farmakologiczne - metyldopę w dawce $500 \mathrm{mg} /$ dobę oraz kwas acetylosalicylowy w dawce $75 \mathrm{~g} /$ dobe [5]. Wizyty kontrolne u kardiologa odbyły się w 25., 30. oraz 34. tygodniu ciąży, w czasie których za każdym razem oceniano wyniki OBPM i HBPM. Wyniki pomiarów BP po rozpoczęciu terapii przedstawiono w tabeli 2. Pacjentka urodziła siłami natury córkę w 38. tygodniu ciąży. Dziecko otrzymało 10 pkt. w skali Apgar. Chora zgłosiła się 3 tygodnie po porodzie na kontrolną wizytę kardiologiczną. W leczeniu utrzymano metyldope w dotychczasowej dawce; w trakcie leczenia w HBPM wyniki większości pomiarów pozostawały powyżej 135/85 mm Hg, maksymalnie 145/88 mm Hg, natomiast w OBPM - powyżej 140/90 mm Hg. Dawkę metylodopy zwiększono do $1000 \mathrm{mg} /$ dobę. W trakcie kolejnej wizyty po 3 tygodniach nie obserwowano poprawy kontroli BP. Ze względu na wolę karmienia piersią, niskie ryzyko sercowo-naczyniowe u chorej z AH 1. stopnia i brak właściwej kontroli BP za pomocą leków dopuszczalnych do stosowania w trakcie ciąży na czas laktacji odstąpiono od leczenia farmakologicznego. Chora pozostawała pod kontrolą ambulatoryjną, a wartości BP w HBPM nie przekraczały 150/95 mm Hg. W czasie karmienia piersią pacjentka czuła się dobrze. Zgłosiła się na wizytę kontrolną po zaprzestaniu karmienia piersią, 6 miesięcy po porodzie. Wartości BP w HBPM wynosiły maksymalnie
159/92 mm Hg. Pacjentka rozpoczęła stosowanie skutecznej antykoncepcji. Włączono u niej inhibitor konwertazy angiotensyny (ACE, angiotensin-converting enzyme) - lisinopril, optymalizując stopniowo dawkę, a następnie dołączono diuretyk tiazydowy, uzyskując prawidłowe wartości BP w HBPM i OBPM.

\section{Omówienie}

Chorobę nadciśnieniową u kobiet w okresie ciąży można zakwalifikować jako: 1) uprzednio występujące AH (przewlekłe $A H), 2) A H$ wywołane ciążą, 3) przewlekłe AH z nałożonym AH wywołanym ciążą oraz 4) AH niedające się sklasyfikować przed porodem. W celu ostatecznego rozpoznania $\mathrm{AH}$ i określenia jego postaci u opisywanej chorej poddano ją ABPM oraz ustalono czas pojawienia się podwyższonych wartości BP. W omawianym przypadku choroba nadciśnieniowa rozwinęła się po 20. tygodniu ciąży, co wstępnie upoważniało do rozpoznania AH indukowanego ciążą [2-4]. Według PTNT i European Society of Cardiology (ESH) w AH indukowanym ciążą podwyższone wartości BP występują do 6. tygodnia od rozwiązania [3]. U omawianej pacjentki AH rozpoznano po 20. tygodniu ciąży, ale nie ustąpiło 6 tygodni od rozwiązania. Kwalifikację typu AH zmieniono zatem na niesklasyfikowane. U tej chorej w czasie ciąży wdrożono leczenie farmakologiczne metyldopą w dawce 2 razy $250 \mathrm{mg} /$ dobę] oraz zleconą częstą kontrolę BP. Jak wiadomo, w okresie ciąży nie zaleca się kobietom z AH ograniczenia spożycia soli. U prezentowanej chorej w czasie ciąży stosunkowo niewielka dawka metyldopy wystarczała do uzyskania prawidłowych wartości BP. Po niepowikłanym porodzie pacjentka rozpoczęła karmienie piersią i mimo stosowanego leczenia, w tym podwojenia dotychczas stosowanej dawki metyldopy, nie udało się uzyskać prawidłowych wartości BP. Możliwe, że wpłynęły na to czynniki emocjonalne związane z macierzyństwem, zaburzenie rytmu dobowego czy też odmienne niż w czasie ciąży zjawiska patofizjologiczne odpowiadające za wzrost wartości BP.

Bezwzględnie przeciwwskazane podczas karmienia piersią, podobnie jak w okresie ciąży, są: inhibitory ACE, sartany, inhibitory reniny, antagoniści aldosteronu, diltiazem. Przedstawione obostrzenia względem leków są podyktowane troską o bezpieczeństwo dziecka, ponieważ wszystkie leki hipotensyjnie przenikają do mleka kobiecego $[2,3,5]$. Powszechnie przyjęte zasady farmakoterapii u matek karmiących uwzględniają przyjmowanie leków mało toksycznych, krótkodziałających, które docelowo osiągają niskie stężenia w mleku matki. Opisaną chorą pozostawiono bez leczenia farmakologicznego na czas karmienia piersią. W przypadku chorych z niepowikłanym AH 1. stopnia ryzyko sercowo-naczyniowe jest niskie i odstąpienie od leczenia farmakologicznego na czas laktacji jest bezpieczne. Według wytycznych w okresie 
laktacji dopuszcza się stosowanie tych samych leków, co w okresie ciąży, jednak u chorych na AH 1. stopnia i nieobciążonych czynnikami ryzyka można bezpiecznie odstąpić od leczenia [6].

\section{Podsumowanie}

Do rozpoznania $A H$ w okresie ciąży konieczny jest wynik ABPM. Leczenie farmakologicznie należy wdrożyć wtedy, gdy BP osiąga wartość 150/95 mm Hg i więcej u kobiet z uprzednio istniejącym $\mathrm{AH}$, natomiast u kobiet $\mathrm{z} \mathrm{AH}$ indukowanym ciążą - już od wartości większej lub równej 140/90 mm Hg. W okresie laktacji dopuszczalne są te same leki, co stosowane w okresie ciąży. U chorych z niepowikłanym AH 1. stopnia można bezpiecznie odstąpić od leczenia hipotensyjnego.

\section{Konflikt interesów}

Autorzy nie zgłaszają konfliktu interesów.

\section{Abstract}

We present a 40-year-old woman with pregnancy-induced hypertension, which was diagnosed in her first pregnancy. The study data demonstrate that patient's blood pressure normalised after applying methyldopa. However, this hypertension treatment came out to be insufficient in the postpartum period. The aim of this study is to present the treatment of hypertension in a breastfeeding patient.

Key words: arterial hypertension, lactation, methyldopa

Folia Cardiologica 2018; 13, 2: 169-172

\section{Piśmiennictwo}

1. Bramham K, Parnell B, Nelson-Piercy $C$, et al. Chronic hypertension and pregnancy outcomes: systematic review and meta-analysis. BMJ. 2014; 348: g2301, indexed in Pubmed: 24735917.

2. Marrs JC, Thompson AM. Antihypertensive therapy in females: a clinical review across the lifespan. Pharmacotherapy. 2016; 36(6): 638-651, doi: 10.1002/phar.1754, indexed in Pubmed: 27072935.

3. Tykarski, A. Zasady postępowania w nadciśnieniu tętniczym - 2015 rok. Nadciśnienie Tętnicze w Praktyce. 2015; 1(1): 1-70.

4. O'Brien E, Parati G, Stergiou G, et al. European Society of Hypertension Working Group on Blood Pressure Monitoring. European So- ciety of Hypertension position paper on ambulatory blood pressure monitoring. J Hypertens. 2013; 31(9): 1731-1768, doi: 10.1097/ /HJH.0b013e328363e964, indexed in Pubmed: 24029863.

5. Rapacz A, Filipek B. Nadciśnienie tętnicze w ciąży. Farm Pol. 2009; 65(8): 581-585.

6. Polska K. Wytyczne ESH/ESC dotyczące postępowania w nadciśnieniu tętniczym w 2013 roku. Kardiol Pol. 2013; 71(Suppl III): 27-118, doi: 10.5603/kp.2013.0177.

7. Vest AR, Cho LS. Hypertension in pregnancy. Curr Atheroscler Rep. 2014; 16(3): 395, doi: 10.1007/s11883-013-0395-8, indexed in Pubmed: 24477794. 